\title{
Summer Snow Dens Used By Polar Bears In The Canadian High Arctic
}

\author{
R. E. SCHWEINSBURG
}

\begin{abstract}
This paper describes the use of snow dens by polar bears during two summers on northern Baffin and Bylot Islands. More dens were found during 1976 than 1975, probably because of heavier snow during 1976. Dens were of three types, shallow surface pits, shallow dens, and deep burrows.
\end{abstract}

This paper describes, for the first time, the use of snow dens by polar bears (Ursus maritimus Phipps) during the summer. Polar bears have long been known to use snow dens during winter throughout their range (Harington, 1968; Lфnф, 1970; Jonkel et al., 1972; Uspenski and Kistchinski, 1972; Lentfer, 1976). These dens provide escape from inclement weather for probably all sex and age classes of polar bears and maternity shelter for parturient females (Harington, 1968; Van de Velde, 1971).

Polar bears also use earth dens during the summer along the coasts and on the islands of southern Hudson and James Bays as places to avoid heat and insects when they come onto land during the ice free period (Jonke et al., 1972). Some earth dens may be used for winter maternity dens.

Jonkel et al., (1972) mentioned the use of snow dens by polar bears in the high Arctic during the summer, but they did not describe these dens in detail. This paper describes some characteristics of the snow dens found during the late summers of 1975 and 1976 and relates numbers of dens found to the climatic conditions during the two seasons.

Observations of summer snow dens were made from a helicopter during polar bear capture surveys on northern Brodeur and Borden Peninsulas, Baffin Island and Bylot Island (Fig. 1).

Climatic conditions differed radically between August 1975 and 1976 (Table 1). Little snow fell during the 1975 field season and only the high ice fields of Brodeur and Bylot Island received fresh snow. Only a few remnant snow banks remained in the lowlands. In 1976 there were numerous snow storms in August and snow covered the ground to the shorelines. Wind driven snow formed deep drifts on the sides of land surface irregularities. The lack of snow precluded tracking bears during August, 1975, except on the high ice fields; conversely during August, 1976, snow cover facilitated tracking of bears.

During 1975, tracks occurred only in the fresh snow on the high ice fields. Only one day bed, a shallow surface pit, was located on an ice field on northern Borden Peninsula at about 1,056 m (3,200 ft) elevation. A three year old male was captured nearby. Numerous other bears loafed or lay on the lower beaches and coastal plains. 


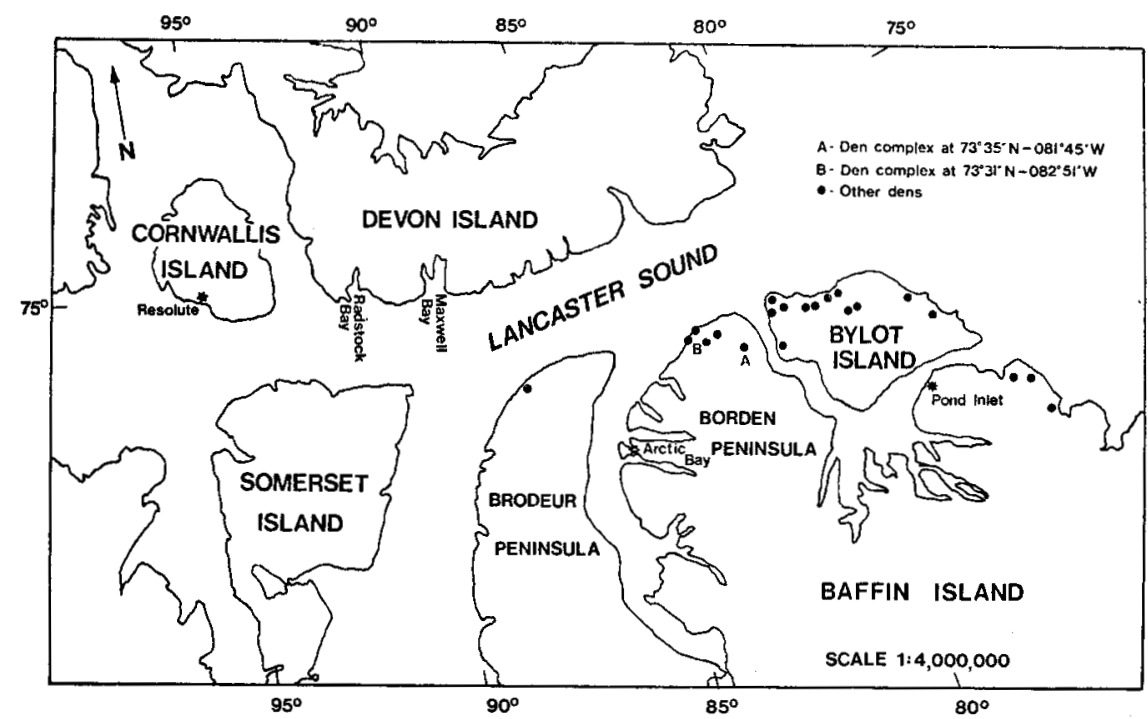

FIG. 1. Locations of polar bear summer snow dens or den complexes on north Baffin and Bylot Islands.

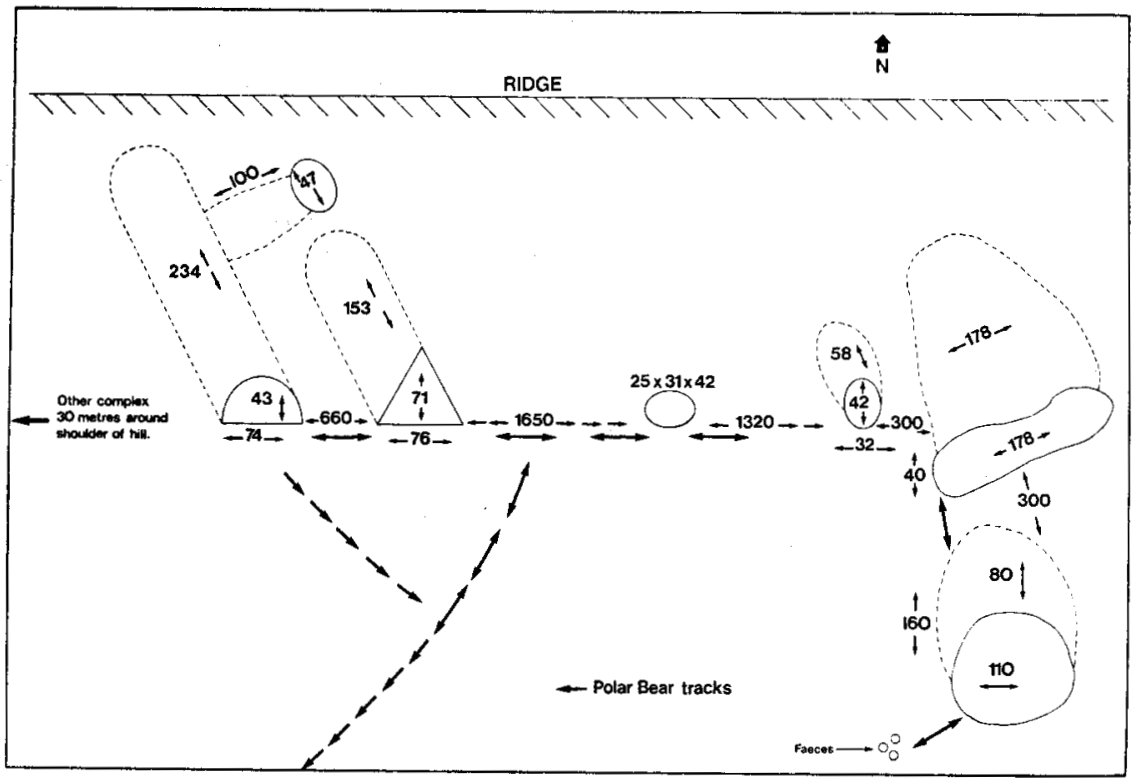

FIG. 2. Schematic drawing of den complex found at $73^{\circ} 31^{\prime} \mathrm{N}, 082^{\circ} 51^{\prime} \mathrm{W}$. All measurements are in centimeters.

Conversely during 1976, numerous tracks and dens were found. Tracks occurred along the northern coastal plains of all land areas, and as high as $1,155 \mathrm{~m}(3,500 \mathrm{ft})$ on the glaciers of Bylot Island. Many tracks occurred inland in steep canyons and at the very tops of mountain ridges, especially on 
southeast Bylot Island. I followed tracks of a female and cub as far as $56 \mathrm{~km}$ inland on north Baffin Island and tracks of a single bear $48 \mathrm{~km}$ inland on Bylot Island. Both sets of tracks headed north toward Lancaster Sound.

Sixty-three individual dens were found at elevations ranging from $33 \mathrm{~m}$ to $660 \mathrm{~m}(100-2,000 \mathrm{ft})$. They varied in type as described in Jonkel et al. (1972) for earth dens; shallow surface pits, shallow dens, and deep dens or burrows. I also found groups or complexes of varying sized dens, which could have been dug by a single bear or by several bears. The most notable den complex occurred at the head of a stream that ran approximately to the northeast at $73^{\circ}$ $35^{\prime}$ N. $081^{\circ} 45^{\prime}$ W. (Loc. A, Fig. 1) where 22 dens were found on top of and in the side of a snowbank on the north side of a deep ravine. The dens were at $495 \mathrm{~m}(1,500 \mathrm{ft})$ elevation and were strung along the snowbank for about 0.8 $\mathrm{km}\left(0.5\right.$ mile). A smaller den complex was found at $73^{\circ} 31^{\prime} \mathrm{N} 082^{\circ} 51^{\prime} \mathrm{W}$ (Loc. B, Fig. 1). This consisted of two deep dens, three shallow dens, and one small scooped area (Fig. 2). The dens were situated with a southern exposure in a snowbank at the top of a ridge at about $231 \mathrm{~m}(700 \mathrm{ft})$ elevation. About $30 \mathrm{~m}$ to the west and out of sight around the shoulder of the ridge was another complex that consisted of four deep dens and four shallow pits.

A four year old male occupied one of the dens at $73^{\circ} 35^{\prime} \mathrm{N} ., 081^{\circ} 45^{\prime} \mathrm{W}$. Other dens may have sheltered bears, but snow filled the entrances and there was no safe way to determine occupancy. Fresh tracks indicated that two adult bears came out of the two complexes at $73^{\circ} 31^{\prime} \mathrm{N} ., 082^{\circ} 51^{\prime} \mathrm{W}$. They travelled directly to the coast and then out over brash ice and cake ice washed against the shore. They must have denned for a considerable length of time, as no tracks led to the dens. In addition to the bears in dens noted above, Table 2 gives the information of other bears found in summer snow dens.

Polar bears are popularly conceived as creatures of the ice or sea. However, when they come on land, they are also at home on rugged mountains and glaciers some distance from the sea. Whether they seek these high places to escapte heat and/or to find den sites is unknown.

Snow conditions influenced the numbers of dens found during the two seasons. Not only did tracks facilitate finding dens, but there were probably many more dens during 1976 than 1975 due to the deep drifts suitable for denning. The inclement weather during 1976 may also have stimulated the bears to den.

Stirling (1974) found two earth summer sleeping pits at Radstock Bay, Devon Island and mentions a personal communication by Jonkel of other summer pits (presumably earth surface pits) at Maxwell Bay and on the north coast, Devon Island. However, summer denning of polar bears in the high Arctic is probably not common in the absence of adequate snow depths. All of the deep dens and most of the surface pits found during 1976 were in snowbanks of new snow.

During tagging operations single unrelated bears were frequently seen in company or near one another. Two or more unrelated bears may also den close together in a den complex. Uspenski and Kistchinski (1972) found winter denning polar bears as close together as 8 to $12 \mathrm{~m}$. 
TABLE 1. Temperature and Precipitation Parameters for August 1975 and 1976 from Atmospheric Environment 1975 and 1976. ${ }^{*}$

\begin{tabular}{|c|c|c|c|c|c|c|}
\hline $\begin{array}{l}\text { Settlement } \\
\text { and Year }\end{array}$ & $\begin{array}{c}\text { Mean } \\
\text { Max. (F) }\end{array}$ & $\begin{array}{c}\text { Mean } \\
\text { Min. (F) }\end{array}$ & $\begin{array}{c}\text { No. Days } \\
\text { Freeze }\end{array}$ & $\begin{array}{l}\text { Precip. } \\
\text { (in.) }\end{array}$ & $\begin{array}{l}\text { Snow } \\
\text { Fall } \\
\text { (in.) }\end{array}$ & $\begin{array}{l}\text { Snow on Ground } \\
\text { at End of } \\
\text { Month (in.) }\end{array}$ \\
\hline $\begin{array}{l}\text { Arctic Bay } \\
\text { (1975) }\end{array}$ & 45.6 & 35.5 & 7 & 1.15 & 0.3 & 0 \\
\hline $\begin{array}{l}\text { Resolute } \\
\text { (1975) }\end{array}$ & 39.5 & 29.6 & 21 & 1.32 & 0.12 & \\
\hline $\begin{array}{l}\text { Pond Inlet } \\
\text { (1976) }\end{array}$ & 41.3 & 28.8 & 25 & 1.88 & 6.6 & 1 \\
\hline $\begin{array}{l}\text { Resolute } \\
\text { (1976) }\end{array}$ & 36.4 & 29.1 & 26 & 1.52 & 7.7 & 1 \\
\hline
\end{tabular}

*Parameters for Arctic Bay are used for 1975 because figures are not available for Pond Inlet. Resolute parameters are given as a check.

TABLE 2. Information on the dens and bears found in dens during late summer 1976.

\begin{tabular}{|c|c|c|c|}
\hline Location & Type of Den & $\begin{array}{l}\text { Elevation } \\
(\mathrm{m})\end{array}$ & $\begin{array}{l}\text { Description } \\
\text { of Bear(s) }\end{array}$ \\
\hline $73^{\circ} 31^{\prime} \mathrm{N}-077^{\circ} 28^{\prime} \mathrm{W}$ & Deep den & 330 & $\begin{array}{l}\text { Estimated } 700 \\
\text { lb. male }\end{array}$ \\
\hline $73^{\circ} 39^{\prime} \mathrm{N}-083^{\circ} 16^{\prime} \mathrm{W}$ & 3 Deep dens & 165 & $\begin{array}{l}\text { Female and } \\
1 / 2 \text { grown cub }\end{array}$ \\
\hline $73^{\circ} 42^{\prime} \mathrm{N}-082^{\circ} 22^{\prime} \mathrm{W}$ & $\begin{array}{l}\text { Hole under stream } \\
\text { snow bank }\end{array}$ & 165 & $\begin{array}{l}\text { Female and two } \\
\text { cubs of year }\end{array}$ \\
\hline $73^{\circ} 50^{\prime} \mathrm{N}-086^{\circ} 15^{\prime} \mathrm{W}$ & Shallow pit & 330 & $\begin{array}{l}\text { Female and two } \\
\text { cubs of year }\end{array}$ \\
\hline $73^{\circ} 41^{\prime} \mathrm{N}-080^{\circ} 04^{\prime} \mathrm{W}$ & 3 Shallow pits & 165 & One small bear \\
\hline $73^{\circ} 38^{\prime} \mathrm{N}-079^{\circ} 23^{\prime} \mathrm{W}$ & Shallow pit & 165 & Single bear \\
\hline $73^{\circ} 37^{\prime} \mathrm{N}-078^{\circ} 50^{\prime} \mathrm{W}$ & Deep den & 198 & $\begin{array}{l}\text { Single bear from } \\
30 \text { August to at } \\
\text { least } 2 \text { September }\end{array}$ \\
\hline $73^{\circ} 40^{\prime} \mathrm{N}-078^{\circ} 50^{\prime} \mathrm{W}$ & 5 Shallow pits & 66 & $\begin{array}{l}11 \text { Year old male } \\
\text { and estimated } \\
600 \mathrm{lb} \text {. male }\end{array}$ \\
\hline $72^{\circ} 35^{\prime} \mathrm{N}-075^{\circ} 47^{\prime} \mathrm{W}$ & $\begin{array}{l}\text { Shallow pit on } \\
\text { glacier }\end{array}$ & 330 & $\begin{array}{l}\text { Estimated } 400- \\
500 \mathrm{lb} \text {. bear }\end{array}$ \\
\hline $73^{\circ} 13^{\prime} \mathrm{N}-076^{\circ} 44^{\prime} \mathrm{W}$ & Shallow den & 198 & $\begin{array}{l}\text { Female and two } \\
\text { cubs of year }\end{array}$ \\
\hline $73^{\circ} 31^{\prime} \mathrm{N}-078^{\circ} 09^{\prime} \mathrm{W}$ & $\begin{array}{l}2 \text { Deep dens on } \\
\text { side of mountain; } \\
\text { one shallow pit on } \\
\text { ridgeback }\end{array}$ & 660 & $\begin{array}{l}\text { Estimated } 600 \\
\text { lb. bear }\end{array}$ \\
\hline
\end{tabular}


Surface pits appear to be day beds that are scooped in the snow. Numerous tracks were followed that ended or were interrupted by a surface pit. Rarely did a bear lie down without digging a surface pit. Shallow dens and deep burrows appeared to be used for a longer period of time.

Summer snow dens may be used later for winter dens. Summer denning polar bears possibly approach physiological conditions similar to winter dormancy, but the fact that several dens were found in a complex and that most bears peeked out at the helicopter or left the den indicated a degree of restlessness uncharacteristic of winter dormancy (Folk et al., 1972). On the other hand, most of the bears caught during late summer were extremely fat. Folk et al. (1972) indicate that fat deposition is necessary for winter dormancy in polar bears and Harington (1968) indicated that snow depth was also very important. Perhaps use of summer snow dens depends on adequate fat deposits and snow depths. Since both conditions existed during late August, 1976, as opposed to late August 1975, the possibility exists that some of the bears continued in their dens through the winter. However, it is not known whether the dens found during August, 1976 were merely temporary shelters to pass the ice free period or more permanent winter dens. The inter-relationships between late summer physiology, fat deposition, snow depth, climatic factors and possible continued summer dormancy into winter months are still unknown.

\section{ACKNOWLEDGEMENTS}

This study was financed by Norlands Petroleums Ltd. and the Northwest Territories Fish and Wildlife Service. Credit for finding the first snow den goes to pilot Dave Small whose interest and help continued throughout the study. Dr. George Calef reviewed the manuscript and suggested several improvements.

\section{REFERENCES}

Atmospheric Environment. Monthly record of meterological records in Canada.

FOLK, E. G. JR., FOLK, M. A. and MINOR, J. J. 1972. Physiological conditions of three species of bears in winter dens. In: Herrero, S. (Ed.) Bears - Their Biology and Management. International Union for the Conservation of Nature New Ser. No. 23. p. 107-124.

HARINGTON, C. R. 1968. Denning habits of the polar bear (Ursus maritimus Phipps). Canadian Wildlife Service Report Series \#5. 33 p.

JONKEL, C., KOLENOSKY, G. B., ROBERTSON, R. J. and RUSSEL, R. H. 1972. Further notes on polar bear denning habits. In: Herrero, S. (Ed.). Bears - Their Biology and Management. International Union for the Conservation of Nature New Ser. No. 23. p. 142-158.

LENTFER, J. W. 1976. Polar Bear Reproductive Biology and Denning. Final Report Federal Aid in Wildife Restoration. Projects W-17-3 and W-17-4. Job 5. 4R. pp. 22.

$\mathrm{L} \emptyset \mathrm{N} \emptyset$, o. 1970. The polar bear (Ursus maritimus Phipps) in the Svalbard area. Norsk Polarinstitutt Skrifter. Norway $149.130 \mathrm{p}$.

STIRLING, 1. 1974. Mid-summer observations on the behavior of wild polar bears (Ursus maritimus). Canadian Journal of Zoology. 52 (9): 1191-1198.

USPENSKI, S. M. and KISTCHINSKI. A. A. 1972. New data on the winter ecology of the polar bear (Ursus maritimus Phipps) on Wrangel Island. In: Herrero, S. (Ed.). Bears - Their Biology and Management. International Union for the Conservation of Nature New Ser. No. 23. p. 181-197.

VAN DE VELDE, F. 1971. Bear Stories. Eskimo - New Series No. 1, Spring-Summer. p. 7-11. 